\title{
IDENTIFIKASI DISIPLIN BELAJAR MAHASISWA SEMESTER III PROGRAM STUDI PENDIDIKAN MATEMATIKA FAKULTAS KEGURUAN DAN ILMU PENDIDIKAN UNIVERSITAS BORNEO TARAKAN
}

\author{
Setia Widia Rahayu ${ }^{1}$, Eka Widyawati ${ }^{2}$ \\ ${ }^{1,2}$ Universitas Borneo Tarakan \\ setia.widiaayu@yahoo.com ${ }^{1}$, eka.adel48@gmail.com ${ }^{2}$
}

Received 26 November 2019; revised 22 June 2020; accepted 27 June 2020.

\begin{abstract}
ABSTRAK
Penelitian yang dilaksanakan bertujuan untuk mengidentifikasi disiplin belajar mahasiswa semester III Program Studi Pendidikan Matematika FKIP Universitas Borneo Tarakan. Adapun metode penelitian yang digunakan dengan menggunakan pendekatan kuantitatif deskriptif. Berdasarkan penelitian yang telah dilaksanakan diperoleh, mahasiswa yang memiliki kategori disiplin belajar sangat tinggi yaitu sebesar 19\% atau sebanyak 11 mahasiswa, dan mahasiswa yang memiliki disiplin belajar pada kategori sedang yaitu sebesar $47 \%$ atau sebanyak 27 mahasiswa, sedangkan mahasiswa yang memiliki disiplin belajar pada kategori rendah sebesar $14 \%$ atau sebanyak 8 mahasiswa, dan mahasiswa yang termasuk dalam kategori sangat rendah sebesar $4 \%$ atau sebanyak 2 mahasiswa.
\end{abstract}

Kata kunci: disiplin belajar, identifikasi, mahasiswa.

\begin{abstract}
The research carried out aims to identify the discipline of student learning in the third semester of the Mathematics Education Study Program FKIP University of Borneo Tarakan. The research method used is descriptive quantitative approach. Based on the research that has been conducted, it is found that students who have a very high learning discipline category are $19 \%$ or as many as 11 students, and students who have a discipline of learning in the medium category that is $47 \%$ or as many as 27 students, while students who have the discipline of learning in the category low of $14 \%$ or as many as 8 students, and students included in the very low category by $4 \%$ or as many as 2 students.
\end{abstract}

Keywords: learning discipline, identification, students. 


\section{PENDAHULUAN}

Matematika adalah salah satu cabang ilmu pengetahuan yang terus dipelajari di setiap jenjang pendidikan, baik Sekolah Dasar, Sekolah Menengah, maupun Perguruan Tinggi (Manik \& Mukhtar, 2017). Matematika dikatakan sebagai ratu dari ilmu pengetahuan, karena seluruh aspek kehidupan manusia tidak terlepas dari matematika (Sholihah \& Mahmudi, 2015). Namun, matematika justru masih dianggap sebagai pelajaran yang menakutkan bagi sebagaian besar siswa. Matematika dianggap sebagai pelajaran yang paling sulit dan tidak mudah dipahami (Unengan, Ainy, \& Mursyidah, 2020). Kondisi tersebut menyebabkan keingintahuan untuk mempelajari matematika relatif rendah. Sedangkan modal utama untuk memahami matematika adalah minat, motivasi, rasa ingin tahu dan kedisiplinan belajar yang tumbuh dari dalam diri individu itu sendiri (Arikunto, 2013).

Pendidikan matematika adalah salah satu program studi yang ada di Fakultas Keguruan dan Ilmu Pendidikan Universitas Borneo Tarakan. Jurusan pendidikan matematika setiap tahun ajaran baru perkuliahan menerima sekitar 80 mahasiswa. Faktor yang melatarbelakangi pemilihan jurusan pendidikan matematika ini sedikit banyak akan mempengaruhi semangat, motivasi bahkan disiplin belajar mahasiswa itu sendiri. Seiring dengan pendapat Tu'u (2004) yang mengemukakan bahwa disiplin belajar sangat penting untuk ditanamkan pada siswa, sehingga siswa menjadi sadar bahwa dengan disiplin akan tercapai prestasi belajar yang optimal.

Berdasarkan dari kondisi tersebut, maka dilakukan penelitian yang tentang identifikasi disiplin belajar mahasiswa semester III Program Studi Pendidikan Matematika, Fakultas Keguruan dan Ilmu Pendidikan, Universitas Borneo.

\section{METODE PENELITIAN}

Penelitian ini menggunakan pendekatan kuantitatif karena jenis data yang dianalisis adalah data berupa angka. Adapun dalam penelitian ini tidak diadakan perlakuan secara langsung kepada mahasiswa tetapi memberikan angket untuk mengetahui disiplin belajar yang dimiliki mahasiswa. Penelitian ini dilaksanakan pada semester ganjil tahun akademik 2019/2020. Lokasi penelitian ini adalah Universitas Borneo Tarakan, Kelurahan Pantai Amal, Kecamatan Tarakan Timur. 
Populasi dalam penelitian ini adalah seluruh mahasiswa Program Studi Pendidikan Matematika semester III sejumlah 85 orang. Adapun sampel dalam penelitian ini berjumlah 58 orang. Teknik pengambilan sampel pada penelitian ini menggunakan teknik sample random sampling (sampel acak sederhana).

Penelitian ini menggunakan instrument atau alat penelitian berupa angket. Dalam penelitian ini, angket yang digunakan berfungsi untuk mengetahui data tentang disiplin belajar. Adapun indikator disiplin belajar yang akan digunakan dalam penelitian ini adalah:

1. Ketaatan terhadap tata tertib universitas, meliputi:

a) datang dan pulang tepat waktu,

b) tertib dalam berpakaian, dan

c) patuh kepada guru dengan mendengarkan nasehat baik saat pelajaran maupun di luar pelajaran.

2. Ketaatan terhadap kegiatan pembelajaran di universitas, meliputi:

a) kesungguhan terhadap kegiatan pembelajaran,

b) tertib saat belajar di kelas, dan

c) penggunaan fasilitas.

3. Ketaatan dalam mengerjakan tugas-tugas, meliputi:

a) ketaatan menyelesaikan tugas,

b) ketaatan mengerjakan tugas rumah, dan

c) mengerjakan soal ujian.

4. Ketaatan belajar di rumah, meliputi:

a) ketaatan pada aturan di rumah,

b) keteraturan belajar di rumah, dan

c) disiplin waktu dalam belajar di rumah.

Teknik penilaian yang digunakan pada angket tersebut adalah menggunakan teknik skala likert. Menurut Sugiyono (2016), skala likert digunakan untuk mengukur sikap, pendapat dan persepsi seseorang atau sekelompok orang tentang fenomena sosial. Jawaban setiap item instrumen menggunakan skala likert yang mempunyai gradasi dari sangat positif sampai sangat negatif (Sugiyono, 2016). Setiap pernyataan mempunyai alternatifalternatif yang diberi skor seperti pada Tabel 1 . 
Tabel 1. Kriteria Penilaian Angket

\begin{tabular}{cccc}
\hline Pernyataan Positif & Skor & Pernyataan Negatif & Skor \\
\hline Selalu & 4 & Selalu & 1 \\
Sering & 3 & Sering & 2 \\
Kadang-kadang & 2 & Kadang-kadang & 3 \\
Tidakpernah & 1 & Tidakpernah & 4 \\
\hline \multicolumn{2}{c}{ Sumber: (Sugiyono, 2016) }
\end{tabular}

Angket digunakan untuk mengumpulkan data kuantitatif serta untuk mengetahui disiplin belajar yang dimiliki mahasiswa. Angket yang diberikan terdiri dari 45 item, berupa pertanyaan berbentuk kalimat positif dan negatif. Angket yang digunakan dalam penelitian ini, menggunakan indikator-indikator disiplin belajar yang dikemukakan oleh Daryanto (2013). Instrumen angket telah divalidasi dan uji coba terlebih dahulu.

Selanjutnya untuk nilai rata-rata (mean) ini didapat dengan menjumlahkan data seluruh individu dalam kelompok itu, kemudian dibagi dengan jumlah individu yang ada pada kelompok tersebut. Hal ini dapat dirumuskan seperti rumus berikut (Sugiyono, 2013):

$$
\bar{X}=\frac{\sum x i}{n}
$$

Keterangan:

$X \quad=$ Rata-rata $(m e a n)$

$\Sigma x i=$ Jumlah nilai $x$ pertama sampai ke- $n$

$n \quad=$ Jumlah individu

Simpangan baku dengan simbol $(s)$ dirumuskan seperti rumus berikut (Supardi, 2013):

$$
s=\sqrt{\frac{\sum(X i-\bar{X})^{2}}{(n-1)}}
$$

Keterangan:

$S \quad=$ Simpangan baku sampel

$X i-X=$ Jarak antara nilai individu dengan rata-rata (simpangan)

$n-1=$ Derajat Kebebasan

Untuk kategori disiplin belajar diberikan pada Tabel 2. 
Tabel 2 Kategori Disiplin Belajar

\begin{tabular}{ccc}
\hline No & Interval & Kategori \\
\hline 1 & $\mathrm{Mi}+1,5 \mathrm{Sdi}<\mathrm{X}$ & Sangat Tinggi \\
2 & $\mathrm{Mi}+0,5 \mathrm{Sdi}<\mathrm{X} \leq \mathrm{Mi}+1,5 \mathrm{Sdi}$ & Tinggi \\
3 & $\mathrm{Mi}-0,5 \mathrm{Sdi}<\mathrm{X} \leq \mathrm{Mi}+0,5 \mathrm{Sdi}$ & Sedang \\
4 & $\mathrm{Mi}-1,5 \mathrm{Sdi}<\mathrm{X} \leq \mathrm{Mi}-0,5 \mathrm{Sdi}$ & Rendah \\
5 & $\mathrm{X} \leq \mathrm{Mi}-1,5 \mathrm{Sdi}$ & Sangat Rendah \\
\hline & & Sumber: Aswar (2013)
\end{tabular}

Keterangan:

$\mathrm{X} \quad=$ Nilai yang diperoleh siswa

Mi = Mean ideal

$=\frac{1}{2}($ Nilai tertinggi ideal + Nilai terendah ideal $)$

Sdi $=$ Standar deviasi ideal

$=\frac{1}{6}($ Nilai tertinggi ideal - Nilai terendah ideal $)$

\section{HASIL PENELITIAN DAN PEMBAHASAN}

Data hasil penelitian ini terdiri atas satu variabel yaitu disiplin belajar. Jumlah responden dalam penelitian ini adalah 58 mahasiswa semester III Program Studi Pendidikan Matematika. Data pada penelitian ini diperoleh dari instrumen berupa angket, yaitu angket disiplin belajar. Data hasil perhitungan angket dianalisis berdasarkan skala likert, dan data dari masing-masing variabel penelitian disajikan dalam tabel deskripsi data.

Berdasarkan pengumpulan data dan penelitian yang telah dilakukan di lapangan diperoleh hasil seperti pada Tabel 3.

Tabel 3. Kelompok Kategori Disiplin Belajar Mahasiswa

\begin{tabular}{cccc}
\hline Interval & Kategori & Frekuensi & Persentase (\%) \\
\hline $146,25<\mathrm{X}$ & Sangat Tinggi & 11 & $19 \%$ \\
$123,75<\mathrm{X} \leq 146,25$ & Tinggi & 15 & $26 \%$ \\
$101,25<\mathrm{X} \leq 123,75$ & Sedang & 27 & $47 \%$ \\
$78,75<\mathrm{X} \leq 101,25$ & Rendah & 8 & $14 \%$ \\
$\mathrm{X} \leq 78,75$ & Sangat Rendah & 2 & $4 \%$ \\
\hline Jumlah & & $\mathbf{5 8}$ & $\mathbf{1 0 0}$ \\
\hline
\end{tabular}

Berdasarkan tabel disiplin belajar mahasiswa (Tabel 3), tampak kategori disiplin belajar mahasiswa paling besar adalah kategori sedang, yaitu $47 \%$ atau 
sebanyak 27 mahasiswa, sedangkan mahasiswa yang memiliki disiplin belajar pada kategori sangat rendah hanya sebesar $4 \%$ atau sejumlah 2 mahasiswa saja. Untuk mempermudah melihat kondisi disiplin belajar mahasiswa semester III program studi Pendidikan Matematika, Fakultas Keguruan dan Ilmu Pendidikan, Universitas Borneo Tarakan pada semester ganjil tahun akademik 2019/2020 diberikan visualisasi seperti pada Gambar 1 .



Gambar 1. Persentase Disiplin Belajar Mahasiswa

Mahasiswa dengan disiplin belajar ketegori sedang memenuhi indikator taat terhadap peraturan di kampus, selalu mengikuri perkuliahan tepat waktu, taat terhadap kegiatan pembelajaran, taat dalam mengerjakan tugas-tugas, tidak pernah meninggalkan tugas yang diberikan dosen, namun tidak memenuhi indikator taat belajar di rumah. Sebanyak $47 \%$ mahasiswa memenuhi indikator-indikator tersebut, artinya sebagian besar semester III Program Studi Pendidikan Matematika, Universitas Borneo Tarakan tahun akademik 2019/2020 memiliki disiplin belajar di kampus dan dalam mengerjakan tugas namun mereka rata-rata tidak mempunyai waktu khusus belajar mandiri di rumah.

Adapun mahasiswa yang termasuk dalam kategori disiplin belajar sangat rendah, hanya memenuhi indikator taat terhadap tata tertib di kampus, dan taat terhadap kegiatan pembelajaran. Hal tersebut berarti hanya sebanyak $4 \%$ mahasiswa semester III Program Studi Pendidikan Matematika, Universitas Borneo Tarakan tahun akademik 2019/2020 yang sering tidak mengumpulkan 
tugas-tugas perkuliahan tepat waktu, serta tidak melakukan belajar secara mandiri di rumah.

\section{SIMPULAN}

Berdasarkan hasil penelitian yang diperoleh, mahasiswa yang memiliki kategori sangat tinggi yaitu sebesar 19\% atau sebanyak 11 mahasiswa, mahasiswa yang memiliki disiplin belajar pada kategori sedang yaitu sebesar $47 \%$ atau sebanyak 27 mahasiswa, sedangkan mahasiswa yang memiliki disiplin belajar pada kategori rendah sebesar $14 \%$ atau sebanyak 8 mahasiswa, dan mahasiswa yang memeiliki kategori sangat rendah sebesar $4 \%$ atau sebanyak 2 mahasiswa.

\section{DAFTAR PUSTAKA}

Arikunto, S. (2013). Dasar-dasar evaluasi pendidikan, edisi 2. Jakarta: Bumi Aksara.

Aswar, S. (2013). Penyusunan skala psikologi, edisi 2. Yogyakarta: Pustaka Pelajar.

Daryanto. (2013). Belajar dan mengajar. Bandung: Yrama Widya.

Manik, M., \& Mukhtar. (2017). Penerapan metode penemuan terbimbing dalam upaya meningkatkan kemampuan pemahaman konsep matematika di kelas VIII SMP negeri 1 Ajibata. Inspiratif: Jurnal Pendidikan Matematika, 3(2), 92-101. https://doi.org/10.24114/jpmi.v3i2.8906.

Tu'u, T. (2004). Peran disiplin pada perilaku dan prestasi siswa. Jakarta: Grasindo.

Sholihah, D. A., \& Mahmudi, A. (2015). Keefektifan experiental matematika MTs materi bangun ruang sisi datar. Jurnal Riset Pendidikan Matematika, 2(2), 175-185. https://doi.org/10.21831/jrpm.v2i2.7332.

Sugiyono, P. D. (2013). Statistik untuk penelitian. Bandung: CV. Alvabeta.

Sugiyono. (2016). Metode penelitian pendidikan (pendekatan kuantitatif, kualitatif, dan $R \& D)$. Bandung: Alfabeta.

Supardi, U. S. (2013). Aplikasi statistika dalam penelitian. Jakarta: Change Publisher.

Unengan, I. R., Ainy, C., \& Mursyidah, H. (2020). Implementasi model kooperatif TGT dengan media ludo math untuk meningkatkan hasil dan motivasi belajar siswa. Jurnal Riset Teknologi dan Inovasi Pendidikan (JARTIKA), 3(1), 113-126. https://doi.org/10.36765/jartika.v3i1.21. 